\title{
THE CHARACTERISTICS OF ASSESSMENT INSTRUMENT FOR CREATIVE THINKING ABILITY ON CRUDE OIL TOPIC
}

\author{
Nanda Resti Monika',Maria Erna ${ }^{2}$, Rasmiwetti ${ }^{3}$ \\ (renandresti15@gmail.com) \\ Postgraduate Department of Chemistry Education, FKIP, University of Riau \\ Pekanbaru, 28293, Riau, Indonesia
}

\begin{abstract}
The development of globalization era also has an impact on the change in the world of education. The education which is demanded in the learning process is 21 st-century learning. One of the important aspects of $21 \mathrm{st}-$ century learning is requiring the students to have the ability to think creatively. Creative thinking ability of the students in the learning process is not apart from the teachers' role. The description of students' creative thinking ability is measured by conducting an assessment. This research aims to know the characteristics of assessment instruments for creative thinking on crude oil topic (construct validity, reliability, the level of difficulty, and question differentiation). This research used Research and Development (R\&D) method which referred to Borg and Gall model. The technique of selecting the samples was Purposive Random Sampling. The research samples were 80 students of Grade XII Senior High School in Pekanbaru City. The technique of data analysis used SPSS Program 24.0. The results of the validity construct for each question is $>0,208$ with 18 questions are stated valid, the reliability test is 0,846 . The percentage level of difficulty obtained $22,222 \%$ questions are categorized into easy, $61,111 \%$ questions are medium, and $16,667 \%$ questions are categorized into difficult. The percentage of question differentiation obtained $16,667 \%$ questions are good, $66,667 \%$ is fair, and $11,111 \%$ is bad.
\end{abstract}

Keyword: Assessment Instrument, Creative Thinking Ability, Crude Oil

\section{INTRODUCTION}

Chemistry is considered important to be taught as a separate subject at Senior High School. Eka Yuli Sari Asmawati (2018) states that Chemistry can give science capital to the students, Chemistry is defined as the media for nurturing the ability to think in order to solve the problem in daily life.

International Journal of Educational Best Practices (IJEBP)

Vol. 3 No. 2 October 2019

ISSN: 2581-0847

DOI: 10.31258/ijebp.v3n2.p75-84 
The regulation of the Ministry of Education and Culture The Republic of Indonesia Number 20 in 2016 about The Standard of Graduate Competence (SKL) is formulated by considering the purpose of national education which is developing the students' potency in order to be the people who believe in God The Almighty, have noble attitude, healthy, knowledgeable, nimble, creative, independent, and become democratic Indonesian citizen, and responsible. Besides that, in formulating SKL also considers the need of the future and preparing for Indonesian Gold Generation in 2045 based on The Competence of XXI Century, Indonesia Demography Bonus and Indonesia Potency become Group 7 of The Biggest Economic Country and at once strengthening Indonesian Contribution towards World Civilization Development. In the explanation of Article 35 The Law Number 20 in 2003, it is stated that SKL is the qualification of graduate ability covering the attitude, knowledge, and skill of the students that must be fulfilled or achieved in certain level of education either elementary or middle level.

International Studies conducted by International Association for the Evaluation of Educational Achievement (IEA), Trends in Mathematics and Science Study (TIMSS) in 2013, explains that Indonesian Chemistry obtains score 397, this score is under the average international score which is 300 (Julia Toblas, et. al., 2014). The result of TIMSS can be used to see the profile of Indonesian students is still low. This occurs because Indonesian students in general still are not trained to solve the problems with characteristics such as TIMSS questions (Eka Yuli Sari Asmawati, 2018).

Adopting the form and type of the questions similar to TIMSS is expected to propel the learning process and at once dig the potency of scientific thinking ability, critical, creative, and innovative. The 21st century is the century when knowledge and technology (IPTEK) develop rapidly. IPTEK development also has an influence on the challenges and global competition for each country included Indonesia. In order to be able to follow the global competition, each country is required to prepare its generation to have 21st Century Skill (Rozita Dass, 2014). The students' success depends on 21st-century skill until they must learn to have it (Rotherham and Willingham, 2009). National Education Association (2002), there are 18 kinds of 21 st Century Skill which the students need to be equipped with. One of them is learning and skills consisting of 4 aspects such as critical thinking, communication, collaboration, and creative thinking.

Maria Erna, et. al., (2018) Curriculum 2013 Revision 2017 which is implemented now also aims to face the demand of education in the global; the curriculum that can generate productive, creative, innovative, and effective Indonesian generation. This is in line with the regulation of the government Number 32 in 2013, the learning process at an education institution is held interactively, inspirative, fun, challenging, motivating the students to actively participate, and giving them enough space to create something and independent according to their talent, interest, and physical and psychological development of the students (Muslim Ibrahim and Rudiman Agustini, 2014).

International Journal of Educational Best Practices (IJEBP)

Vol. 3 No. 2 October 2019

ISSN: 2581-0847

DOI: $10.31258 /$ ijebp.v3n2.p75-84 
The thinking ability which is required in curriculum 2013 one of them is creative thinking (Amalia, et. al., 2015). Creative thinking ability is an ability to find a new relationship, looking at various aspects from a new perspective and finding a new combination of two or more existing concepts (Sibel and Fatma, 2014). Creative thinking ability will form a creative individual in answering global challenges because a creative individual will be able to compete in any condition. Creative thinking ability becomes a very needed ability for the students to face life condition which always experiences changes and development.

Some things that can be done by teachers to stimulate and improve students' thinking ability, attitude, and creative behavior are by implementing the learning model which leads to problem solving and make certain assessment instrument and evaluation towards the process and learning process in line with Permendiknas No. 16 in 2007 about Academic Qualification and Standard Competence of Teachers; implementing assessment and evaluation towards the process and learning achievement. To know if the teaching and learning process has achieved the learning goals implemented need assessment.

Assessment is a very important component in organizing education. The effort to improve the quality of education can be done by improving the quality of learning and assessment (Iqbal Habiby, 2016). Research plan, assessment process, and good learning system will create good learning quality (Docktor and Heller, 2009). This learning quality can be seen in the assessment result. Furthermore, a good assessment will propel the teacher to determine a good learning strategy and motivate the students to study well. Therefore, to improve the education quality, it needs assessment revision to be implemented (Rasyd and Mansur, 2007).

Considering the condition of curriculum nowadays is curriculum 2013 revision 2017 which expects the students to bring up creativity in the learning process, then written test assessment made by teachers is expected to lead them to bring up creative thinking skill in solving the problem in that assessment. Students' creative thinking ability can be recognized by giving assessment designed in line with the characteristics obtained in the classification of students' creative thinking. Thus, the students are expected not only to understand the topics being taught by the teacher, but also able to implement their creative thought to be used in solving the problem outside school.

Abdul Rahman (2016) based on his research results concludes that there are still found many assessment activities at many schools with assessment not in accordance with the requirements of a good assessment, the teachers do not make a summary of the topic when arranging the questions until the achievement is not measured clearly. The research results by Dian Agustin, et. al., (2015) concludes that there are still many teachers do not make an assessment which measures cognitive domain in line with the basic competence on the topic of atom covering cognitive domain, remembering, understanding, and applying the knowledge. Divergent thinking ability is looking at the ability to answer a certain problem and seldom stimulated and measured (Ulul Faizah, 2018).

International Journal of Educational Best Practices (IJEBP)

Vol. 3 No. 2 October 2019

ISSN: 2581-0847

DOI: $10.31258 /$ ijebp.v3n2.p75-84 
A preliminary study was conducted at State Senior High School Plus Riau Province, State Senior High School 14 Pekanbaru, Islamic Integrated Senior High School Al-Fityah Pekanbaru showed that the teachers of chemistry subject at those schools had used assessment instrument to measure the ability of critical thinking, however still a little for creative thinking assessment. The type of assessment instrument used was in the form of multiple-choice questions, short answer, and essay test however still not referring to the questions for creative thinking ability especially related to crude oil. Crude oil topic is the contextual topic and the application of crude oil is very close to daily life such as gasoline, global warming, and alternative fuel beside crude oil and natural gas until it is suitable to be measure creative thinking ability through creative thinking questions being developed. In line with the opinion of Harry Firman (2013), open description question made by teachers must be contextual materials

\section{RESEARCH METHOD}

This research was conducted in Pekanbaru City, Riau Province. The research samples were 80 students coming from State Senior High School Plus Riau Province, State Senior High School 14 Pekanbaru, and Islamic Integrated Senior High School Al-Fityah Pekanbaru. The technique of taking the samples was Purposive Random Sampling.

The data being collected were in the form of qualitative and quantitative data. Quantitative data were obtained from the result of an interview with the teacher, the up to date research journals, books, and other related sources such as the law of national education system, Permendiknas, curriculum 2013 revision 2017, Kemendikbud, article, thesis, and internet. While quantitative data were obtained from the data score of questions on creative thinking skill ability. Construct validity test, reliability, a test of difficulty level, and question differentiation were processed by using SPSS 24.0 Program.

\section{RESULTS AND DISCUSSION}

This research and development produce the product in the form of questions for measuring creative thinking ability on crude oil topic by considering the characteristics of good questions (construct validity, reliability, question differentiation, and difficulty level).

The examination of construct validity, reliability, question difficulty level, and differentiation was conducted by using SPSS 24.0 Program.

\section{Construct Validity}

International Journal of Educational Best Practices (IJEBP)

Vol. 3 No. 2 October 2019

ISSN: 2581-0847

DOI: 10.31258/ijebp.v3n2.p75-84 
Validity shows the degree of accuracy between the real data happening in the field on the object and the data collected by the researcher (Widoyoko, 2012). Validity test in this research is by using Pearson correlation. After the value of the validity coefficient of each question is obtained, then the result is compared with $r$ value from the table at significance level $5 \%$ and significance level $1 \%$ with $\mathrm{df}=\mathrm{N}-2$. If $\mathrm{r}_{\text {count }}>\mathrm{r}_{\text {table }}$ then validity coefficient of question item validity is at significance level is used (Suharsimi Arikunto, 2010). The following table is the result of the validity test tested towards 80 students.

Table 1. Results of Construction Validity Test

\begin{tabular}{ccccc}
\hline No & $\begin{array}{c}\text { Number of } \\
\text { Questions }\end{array}$ & $\begin{array}{c}\text { Aspects of Creative } \\
\text { Thinking }\end{array}$ & $\mathbf{R}_{\text {count }}$ & Information \\
\hline 1 & $1 \mathrm{a}$ & Elaboration & 0,610 & Valid \\
\hline 2 & $1 \mathrm{~b}$ & Originality & 0,638 & Valid \\
\hline 3 & $1 \mathrm{c}$ & Fluency & 0,678 & Valid \\
\hline 4 & $2 \mathrm{a}$ & Flexibility & 0,508 & Valid \\
\hline 5 & $2 \mathrm{~b}$ & Flexibility & 0,524 & Valid \\
\hline 6 & $3 \mathrm{a}$ & Elaboration & 0,606 & Valid \\
\hline 7 & $3 \mathrm{~b}$ & Elaboration & 0,572 & Valid \\
\hline 8 & $3 \mathrm{c}$ & Flexibility & 0,596 & Valid \\
\hline 9 & $4 \mathrm{a}$ & Elaboration & 0,647 & Valid \\
\hline 10 & $4 \mathrm{~b}$ & Originality & 0,629 & Valid \\
\hline 11 & $4 \mathrm{c}$ & Fluency & 0,698 & Valid \\
\hline 12 & 5 & Flexibility dan Fluency & 0,749 & Valid \\
\hline 13 & $6 \mathrm{a}$ & Flexibility & 0,668 & Valid \\
\hline 14 & $6 \mathrm{~b}$ & Elaboration & 0,194 & Invalid \\
\hline 15 & 7 & Fluency & 0,718 & Valid \\
\hline 16 & $8 \mathrm{a}$ & Elaboration & 0,717 & Valid \\
\hline 17 & $8 \mathrm{~b}$ & Originality & 0,223 & Valid \\
\hline 18 & $8 \mathrm{c}$ & Fluency & 0,559 & Valid \\
\hline 19 & $9 \mathrm{a}$ & Elaboration & 0,431 & Valid \\
\hline 20 & $9 \mathrm{~b}$ & Orginality & 0,164 & Invalid \\
\hline
\end{tabular}

Table 4.8 shows the results of 20 question items validity construct which there are 18 question items valid and two question items invalid. A question is said valid at significance level $5 \%$ if the value is $>2,220$. The invalid question item cannot be used in the research, therefore the invalid data were eliminated. The value of Pearson correlation in Table 4.8 each $R_{\text {count }}>0,220$ if $N=80$, therefore the data that can be used are 18 question items.

\section{Question Reliability}


Reliability test in this research is by using Cronbach Alpha correlation if the value of significance is $>0,6$, then the instrument is categorized into reliable (Ety Rochaety, 2012). The result of the reliability test in this research can be seen in Table 2. as follows:

Table 2. The Result of Reliability Test

\begin{tabular}{cc}
\hline Cronbach's Alpha & N of Items \\
\hline 0,846 & 80 \\
\hline
\end{tabular}

Table 2 shows that the tested variable generates coefficient value Cronbach alpha bigger than 0.6, thus it can be concluded that the instruments are reliable and appropriate to be used.

\section{The Level of Question Difficulty}

Nana Sudjana (2011) the analysis of question difficulty level studies the test questions from the aspect of its difficulty until it obtains the questions categorized into easy, medium, and difficult.

Table 3. The Result fo Question Difficulty Level

\begin{tabular}{lcccc}
\hline $\begin{array}{c}\text { Criteria of } \\
\text { Difficulty Level }\end{array}$ & $\begin{array}{c}\text { Index of } \\
\text { Difficulty } \\
\text { Level }\end{array}$ & $\begin{array}{c}\text { Number } \\
\text { of Questions }\end{array}$ & Total & \% \\
\hline Easy & $0,71-1,00$ & $1 \mathrm{a}, 1 \mathrm{c}, 3 \mathrm{a}, 7$ & 4 & 22.222 \\
\hline Medium & $0,31-0,70$ & $\begin{array}{l}\text { 1b, 2a, 3c, 4a, 4b, 4c, } \\
\text { 6a, 8a, 8b, 8c, 9a }\end{array}$ & 11 & 61,111 \\
\hline Difficult & $0-0,30$ & $2 \mathrm{~b}, 3 \mathrm{~b}, 5$ & 3 & 16,667 \\
\hline
\end{tabular}

Table 3. shows the result of difficulty level which obtains $22,222 \%$ question items are categorized into easy, 61,111\% question items categorized into medium, and 16,667\% categorized into difficult. The assumption used to obtain a good quality of questions, besides fulfilling validity and reliability, is the existence of balance among the difficulty level of those questions. Balance here means there are questions categorized into easy, medium, and difficult proportionally. The comparison between easy-medium-difficult questions can be made 3-4-3, which means 30\% easy questions, $40 \%$ difficult questions, and $30 \%$ difficult questions. Another comparison with the proportion above is 3-52 which means $30 \%$ easy questions, $50 \%$ medium questions, and $20 \%$ difficult questions (Herry Susanto, et. al., 2015).

The percentage of question difficulty level obtained for easy category is $22,222 \%$, medium category is $61,111 \%$, difficult category is $16,667 \%$ approaching the theory proportionally comparison between easy-medium-difficult questions made 3-5-2 is 30\% easy category, $50 \%$ medium category, and 20\% difficult category almost approached, it means the questions being developed have good enough question-level difficulty.

International Journal of Educational Best Practices (IJEBP)

Vol. 3 No. 2 October 2019

ISSN: 2581-0847

DOI: 10.31258/ijebp.v3n2.p75-84 


\section{Question Differentiation}

Question differentiation test is the ability of question to distinguish student competences (Ali Hamzah dan Muhlisrairi, 2014). Question differentiation test is conducted to know the quality of question item among the groups above which answer correctly with the group below which answer correctly (Nana Sudjana, 2011).

Table 4. The Result of Question Differentiation

\begin{tabular}{ccccc}
\hline $\begin{array}{c}\text { Criteria of } \\
\text { Differentiation }\end{array}$ & $\begin{array}{c}\text { Index of } \\
\text { Differentiation }\end{array}$ & Question's Number & Total & \% \\
\hline Very Poor & $\mathrm{DP} \leq 0,00$ & - & - & - \\
\hline Poor & $0,00 \leq \mathrm{Dp} \leq 0,20$ & $2 \mathrm{a}, 3 \mathrm{~b}$ & 2 & 11,111 \\
\hline Fair & $0,20 \leq \mathrm{Dp} \leq 0,40$ & $\begin{array}{c}1 \mathrm{a}, 1 \mathrm{~b}, 1 \mathrm{c}, 2 \mathrm{~b}, 3 \mathrm{c}, 4 \mathrm{a}, 4 \mathrm{~b}, 4 \mathrm{c}, \\
\text { 6a, 6c, 7, 8b, 8c, 9a }\end{array}$ & 12 & 66,667 \\
\hline Good & $0,40 \leq \mathrm{Dp} \leq 0,70$ & $3 \mathrm{a}, 8 \mathrm{a}, 5$ & 3 & 16,667 \\
\hline Excellent & $0,70 \leq \mathrm{Dp} \leq 1,00$ & - & - & - \\
\hline
\end{tabular}

Table 4. shows question differentiation which obtains $16,667 \%$ question items categorized into good, 66,667\% question items categorized into fair, and $11,111 \%$ question items categorized into poor. The results of developing creative thinking questions that have been validated by experts in their fields and analyzed based on good assessment instrument criteria can be seen in table 5 .

Table 5. Questions of Creative Thinking on Crude Oil

\begin{tabular}{|c|c|c|}
\hline $\begin{array}{l}\text { Indicator of } \\
\text { Questions }\end{array}$ & $\begin{array}{c}\text { The aspect of } \\
\text { Creative Thinking }\end{array}$ & Number of questions \\
\hline \multicolumn{3}{|r|}{ Read the text below! } \\
\hline & & $\begin{array}{l}\text { Badan Operasi Bersama (BOB) PT Bumi Siak } \\
\text { Pusako to find new oil reserves from } \\
\text { Benewangi well located in Dayun Village, } \\
\text { Dayun District, Siak regency. The Discovery } \\
\text { of oil reserves obtained from drilling well with } \\
\text { a total depth of } 2.800 \text { feet. However, it has not } \\
\text { been disclosed with certainty how much new } \\
\text { oil reserves have been discovered in this well } \\
\text { (riau.antaranews.com } 11 / 2 / 2019 \text { ) }\end{array}$ \\
\hline $\begin{array}{l}\text { Analyzing the } \\
\text { process of crude oil } \\
\text { formation }\end{array}$ & $\begin{array}{l}\text { Elaboration } \\
\text { Thinking }\end{array}$ & $\begin{array}{l}\text { a. How the process crude oil formation } \\
\text { based on inorganic and organic theory? }\end{array}$ \\
\hline
\end{tabular}

International Journal of Educational Best Practices (IJEBP)

Vol. 3 No. 2 October 2019

ISSN: 2581-0847

DOI: 10.31258/ijebp.v3n2.p75-84 


Imagine the process
of crude oil Thinality
formation

Predict the state of the earth in the future based on global warming data and how to overcome them.
Fluency Thinking

Flexibility Thinking
Global warming is one of the causes of rising temperatures. It is estimated that 90 percent of global warming is due to carbon emissions from human activities. reported by Scientific American, the Intergovernmental Panel on Climate Change (IPCC) researchers revealed that the ocean heats about 40 percent faster than previously estimated (KOMPAS. COM $12 / 01 / 2019,15: 16$ WIB). Try to see from a different perspective what will happen to the earth in 2050 by giving 5 ways to prevent rising temperatures!

These findings are in line with the Minister of National Education Regulation No. 20 of 2007 stating that an educator must be able to develop assessment instruments and assessment guidelines according to their assessment forms and techniques. The statement can be interpreted that the assessment instruments made by educators must be good. Pitri Rahma Dewi (2019) found that questions of creative thinking on acid-base material developed were in good criteria. A good assessment instrument is valid, reliable, and has a level of difficulty and distinguishing features following the guidelines. Besides, the assessment instrument must also be able to measure what should be measured, namely the students' creative thinking abilities.

\section{CONCLUSION}

From the result, it can be concluded that instrument question of creative thinking ability categorized valid and reliable. The level of question difficulty is almost approaching proportion at easy, medium, and difficult category. Question differentiation is on category good, fair, and easy. The means, the instrumented assessment can be used to measure creative thinking ability of students, especially to crude oil topic. 


\section{REFERENCES}

Abdul Rahman, dan Ansari Saleh Ahmar. (2017). Problem Posing of High School Mathematics Student's Based on Their Cognitive Style. Educational Process: International Journal, 6(1), 7-23.

Ali Hamzah \& Muhlisrairi. (2014). Perencanaan dan Strategi Pembelajaran Matematika. Raja Wali Press. Jakarta.

Eka Yuli Sari Asmawati, Undang Rosidin, Abdurrahman. (2018). Effectivity of Assessment Instrument Model Creative Problem Solving on Physics Learning Towards Students' Critical Thinking Ability.Journal of Physics Education, 6(2), 2442-4838.

Daryanto and Karim. S. (2016). $21^{\text {st }}$ Century Learning. Yogyakarta: PT Gava Media.

Dass, R. (2014). Literature and 21 st Century Learner, Jurnal Procedia Social and Behavior ScienceTaylor's University, 123(14), 289-298.

Demir, S. and Sahin, F. (2014). Assessment of Prospective Science Teachers' metacognition and Creativity perceptions and a scientific toys in terms of scientific creativity. Procedia-Social and Behavior 152, 686-691.

Dian Agustin, Nina Kadaritna, Lisa Tania. (2015). Developing Knowledge Assessment Instrument on Topic Theory of Atom Bohr and Quantum Mechanics. Journal of Education and Chemistry Learning, 4(1), 209-221.

Doctor, J. dan Heller, K. (2009). Robust Assessment Instrument for Student Problem Solving. Proceeding the NARST 2009 Annual Meeting, Minnesota university.

Harry Firman. (2013). Chemistry Learning Evaluation. Bandung : Universitas Pendidikan Indonesia Press.

Iqbal Habiby. (2016). Developing Instruments of Creative Thinking Ability on Topic Acid and Alkali Arrhenius. Journal of Chemistry Learning, 12(4): 64-71.

Maria Erna, R. Usman Rery \& Wiji Astuti. (2018). Peningkatan Kemampuan Berpikir Kritis Peserta Didik pada Materi Termokimia di SMA Pekanbaru Melalui Penerapan Strategi Pembelajaran POGIL. Jurnal Riset Pendidikan Kimia, 8(1) :1727.

Muslimin Ibrahim, Rudiana Agustini dan Tilal Afian. (2014). Pengembangan Perangkat Pembelajaran Sains Berorientasi Guided Discovery Untuk Mengajarkan 
Kemampuan Berpikir Kreatif Dan Penguasaan Konsep.Jurnal Pendidikan Sains Pascasarjana Universitas Negeri Surabaya, 4(1)

Nana Sudjana. (2011). Assessment for Teaching Learning Achievement. Bandung : Remaja Rosdakarya.

Pitri Rahma Dewi. (2019). Pengembangan Instrumen Asesmen Untuk Mengukur Kemampuan Berpikir Kreatif Siswa pada materi Asam Basa. Tesis.

Rasyid, H. danMansur. (2007). Achievement Assessment. Bandung : Wacana Prima.

Rotterham, A.J and Willingham, D. (2009). $21^{\text {st }}$ Century Skill: The Chaleenges Ahead. Journal Educational Leadership, 67(1), 16 -21.

Sugiyono. (2012).Educational Research Method Quantitative, Qualitative, and R\&D Approach, Bandung : Alfabeta.

Suharsimi Arikunto. (2010). The Basics of Educational Evaluation. Jakarta : Bumi Aksara.

Sunardi dan Sujadi, I. (2017). Sumber Belajar Calon Peserta Program PLPG Penilaian Dan Evaluasi Pembelajaran. Kementerian Pendidikan Dan Kebudayaan Direktorat Jenderal Guru dan Tenaga Kependidikan.

Toblas, J., Wales., Joseph., Ekki, S., \& Suharti. (2016). Towards Better Education Quality. Indonesia's Promising Path. Development Progress Case Study Summary. London. Overseas Development Institute.

Ulul Faizah, Agus Prasetyo Kurniawan dan Suparto. (2018). Profil Kemampuan Berpikir Divergen Siswa dalam Menyelesaikan Masalah Open Ended. Jurnal Pendidikan Matematika, 43 (3), 44-52

Widoyoko. (2012). Technique of Making Research Instruments. Yogyakarta : Pustaka Belajar. 